\title{
Rancangan Sistem Informasi Pendataan Warga Tidak Mampu di Sekitar DKM Al-Munawwaroh
}

\author{
Larasati Fitria Azizah \\ Telkom University; \\ Email: larasatifa@student.telkomuniversity.ac.id
}

\begin{abstract}
Setiap tahun ketika Hari Raya Idul Adha kerap terjadi kerusuhan entah saat membagi kupon maupun saat pembagian daging gratis. Untuk menghindari kerusuhan yang kerap terjadi diusulkan untuk membuat sistem informasi untuk pendataan bagi warga yang tidak mampu untuk mendapatkan voucher. Kemudian voucher akan diberikan kepada warga yang tidak mampu yang terdapat pada database. Sistem ini dikatakan berhasil saat pembagian daging kurban tidak terjadi kerusuhan.
\end{abstract}

Keywords: sistem informasi, database, kerusuhan

\section{Introduction}

1.1. Business case

Setiap tahun ketika Hari Raya Idul Adha kerap terjadi kerusuhan entah saat membagi kupon maupun saat pembagian daging gratis. Untuk menghindari kerusuhan yang kerap terjadi diusulkan untuk membuat sistem informasi untuk pendataan bagi warga yang tidak mampu untuk mendapatkan voucher. Sehingga pada saat pembagian daging gratis hanya warga yang berhak menerima daging tersebut dan tidak terjadi kerusuhan.

\subsection{System Requirement}

Sistem ini berisi data warga yang tidak mampu. Warga yang tidak mampu akan menyerahkan surat keterangan tidak mampu (SKTM) ke panitia kurban kemudian panitia akan mendata melalui form yang sudah disediakan dan form tersebut akan terekam di database. Kemudian voucher akan diberikan kepada warga yang tidak mampu yang terdapat pada database. Sistem ini dikatakan berhasil saat pembagian daging kurban tidak terjadi kerusuhan.

\section{Penjelasan SIngkat Terkait Metode}

Menurut Pressman (2015:42), model waterfall adalah model klasik yang bersifat sistematis, berurutan dalam membangun software. Nama model ini sebenarnya adalah "Linear Sequential Model". Model ini sering disebut juga dengan "classic life cycle" atau metode waterfall. Model ini termasuk ke dalam model generic pada rekayasa perangkat lunak dan pertama kali diperkenalkan oleh Winston Royce sekitar tahun 1970 sehingga sering dianggap kuno, tetapi merupakan model yang paling banyak dipakai dalam Software Engineering (SE). Model ini melakukan pendekatan secara sistematis dan berurutan. Disebut dengan waterfall karena tahap demi tahap yang dilalui harus menunggu selesainya tahap sebelumnya dan berjalan berurutan. [1]

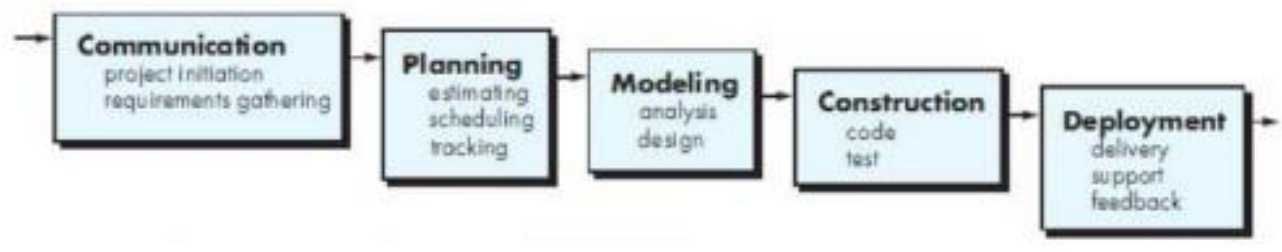




\section{Proses Perhitungan}

\subsection{System Design}

Berikut ini merupakan system design :
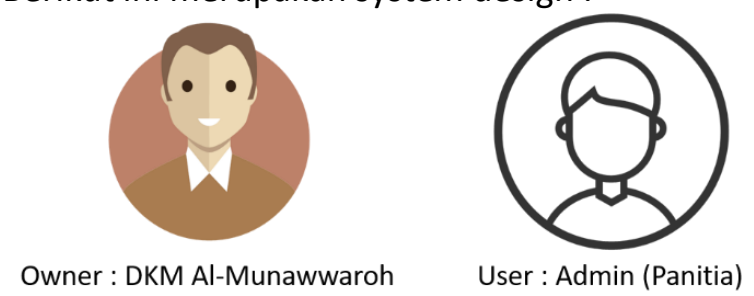

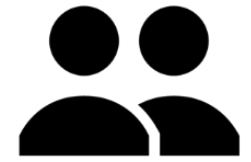

Customer : Warga Tidak Mampu Sekitar DKM Al-Munawwaroh

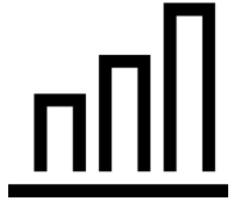

Analyst : Tim Analyst

Figure 2 System Design

Sistem informasi ini dimiliki oleh DKM Al-Munawwaroh, user dari sistem informasi ini adalah admin atau panitia kurban DKM Al-Munawwaroh dan customer atau yang memakai sistem informasi ini adalah warga tidak mampu di sekitar DKM Al-Munawwaroh. Sistem Informasi ini akan di analisis dan dikembangkan oleh tim analis.

\subsection{Data Flow Diagram (DFD)}

Data Flow Diagram atau dalam bahasa Indonesia menjadi Diagram Alir Data (DAD) adalah refresentasi grafik yang menggambarkan aliran informasi dan transformasi informasi yang diaplikasikan sebagai data yang mengatur dari masukan (input) dan keluaran (output). DFD tidak sesuai untuk memodelkan sistem yang menggunakan pemograman berorientasi objek. [2]

Berikut merupakan DFD Level 0 :

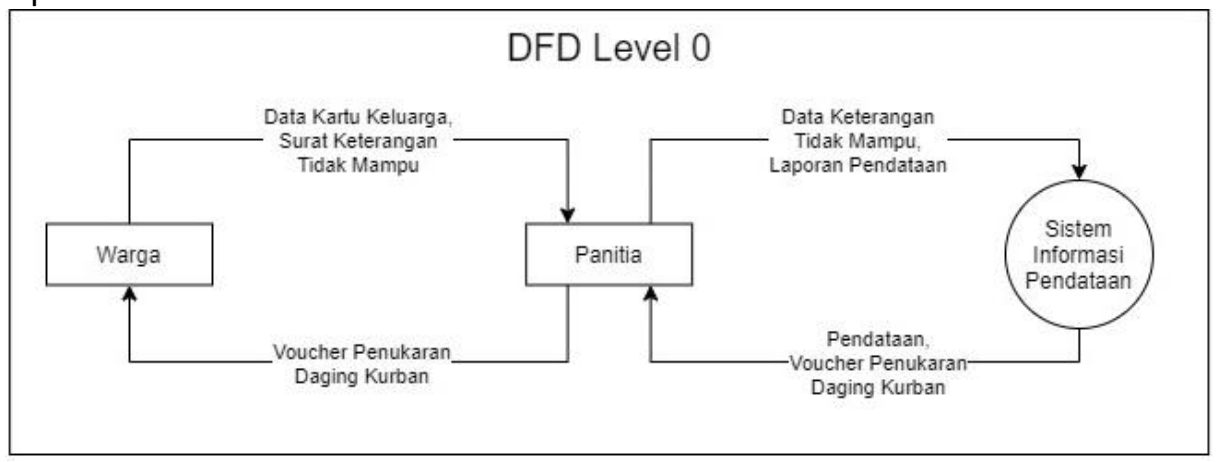

Figure 3 DFD Level 0

Pada DFD level 0 ini pelaku yang menggunakan sistem informasi ini adalah panitia yang bertanggungjawab. Semua kegiatan yang diakses menggunakan sistem informasi ini hanya bisa diakses oleh panitia yang bertanggungjawab dan tidak ada hak akses apapun.

Berikut merupakan DFD Level 1 :

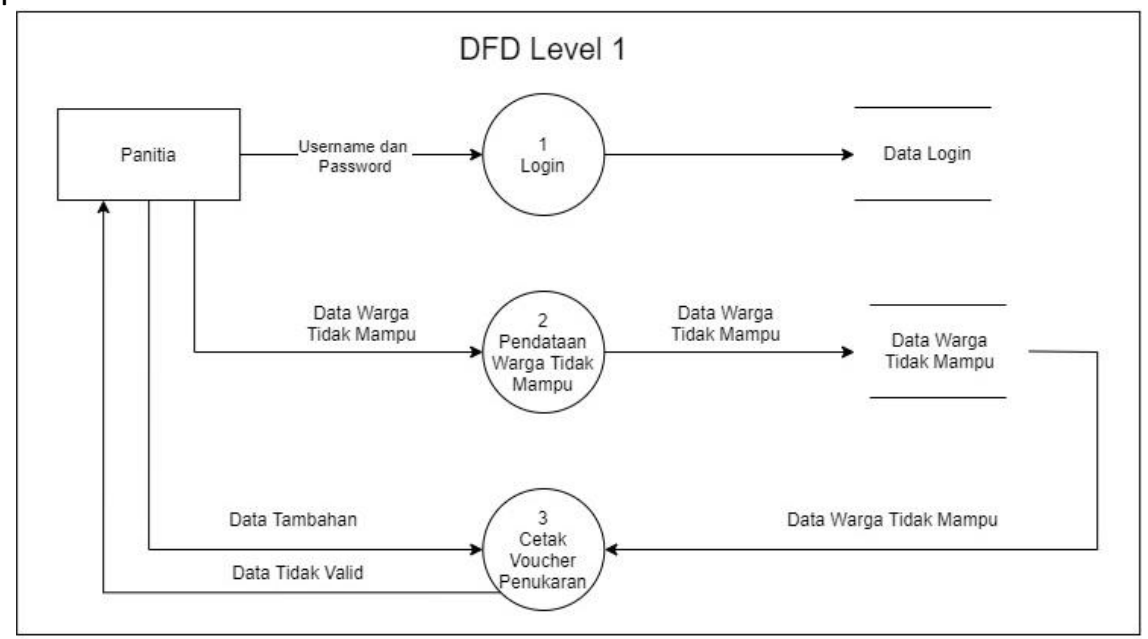

Figure 4 DFD Level 2 
Pada DFD level 1 ini merupakan penjabaran dari sistem informasi ini. Pada DFD level 1 ini tedapat beberapa fungsi seperti login, pendataan warga tidak mampu dan cetak voucher penukaran.

Berikut merupakan DFD Level 2 :

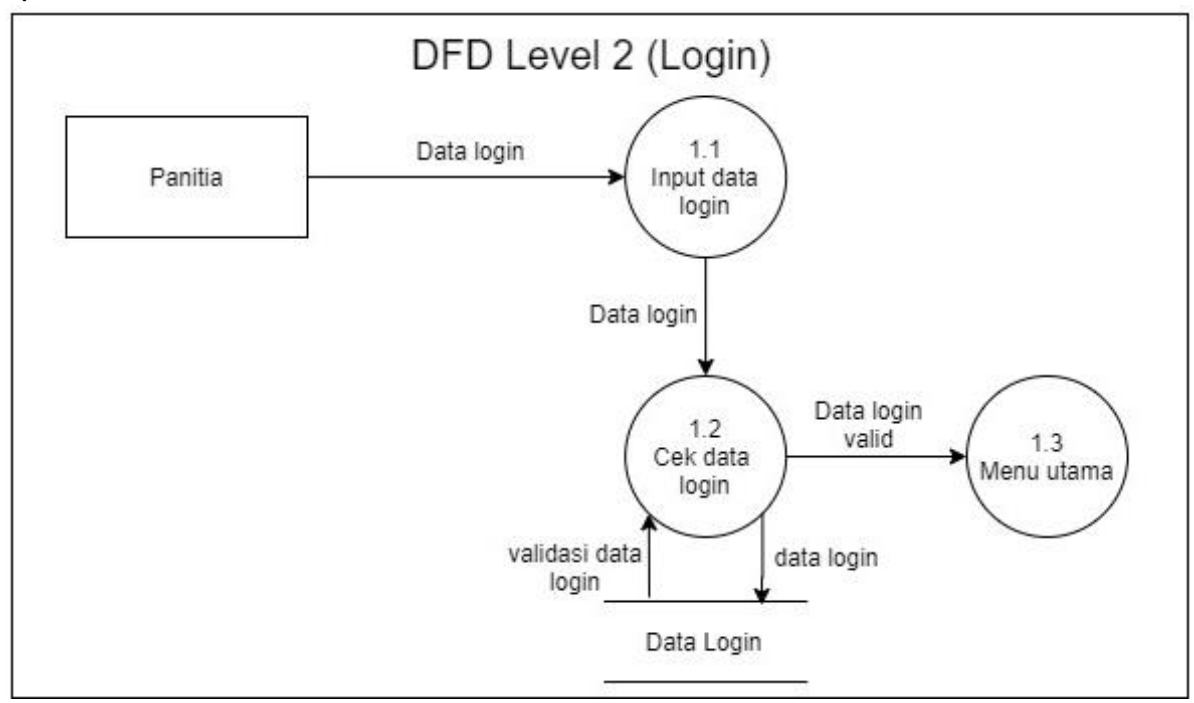

Figure 5 DFD Level 2 (Login)

Untuk DFD level 2 (login), panitia melakukan input data login seperti username dan password. Kemudian sistem akan mengecek apakah data tersebut valid atau tidak, jika valid maka sistem akan meneruskan ke menu utama, jika tidak sistem akan kembali ke menu login dan panitia harus menginput username dan password yang sudah terdaftar.

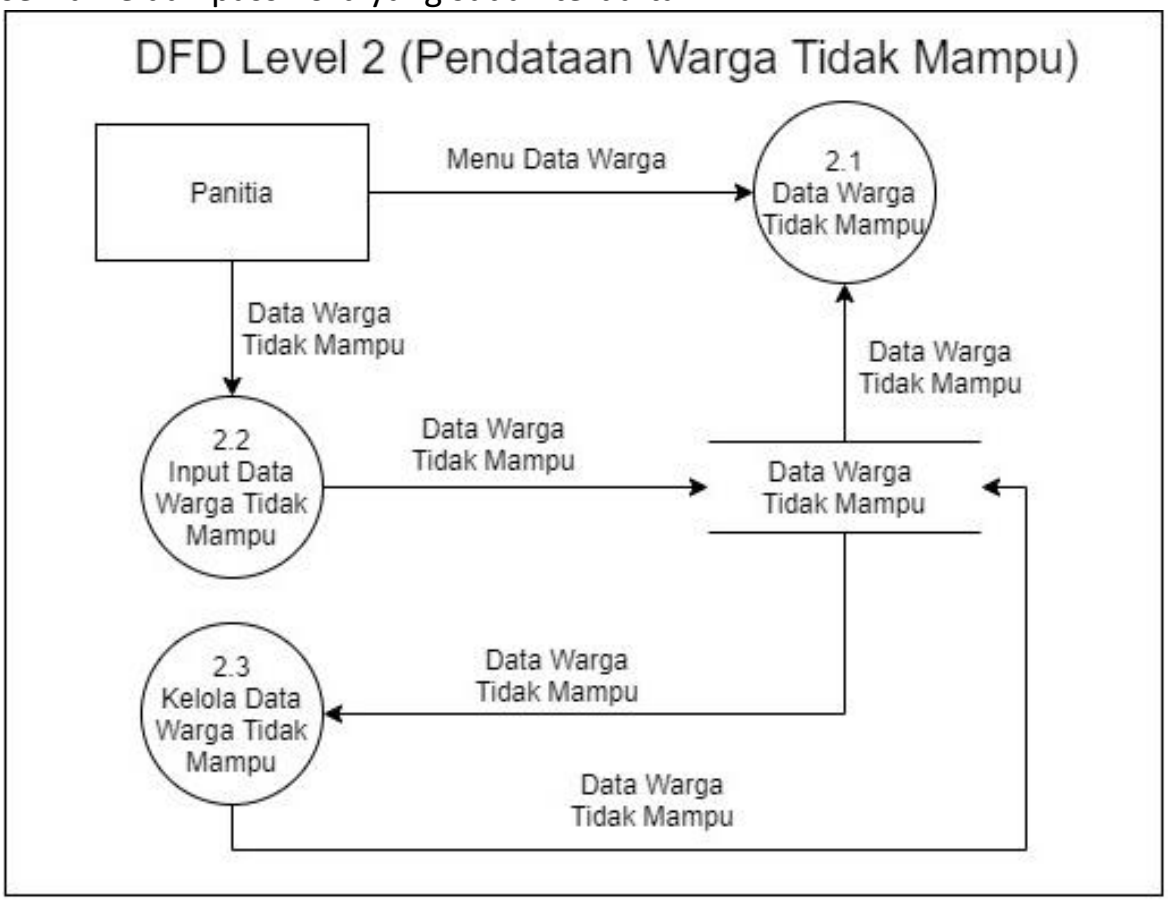

Figure 6 DFD Level 2 (Pendataan Warga Tidak Mampu)

Untuk DFD level 2 (pendataan warga tidak mampu), proses ini dilakukan untuk menambah data warga tidak mampu. Panitia melakukan input data warga tidak mampu seperti nama, no kk, dan surat keterangan miskin. Jika berhasil maka data akan masuk ke database dan ditampilkan pada menu report. Jika ingin mengedit ataupun menghapus maka dipilih melalui database kemudian dieksekusi sesuai dengan perintah maka database akan melakukan perubahan secara otomatis. 


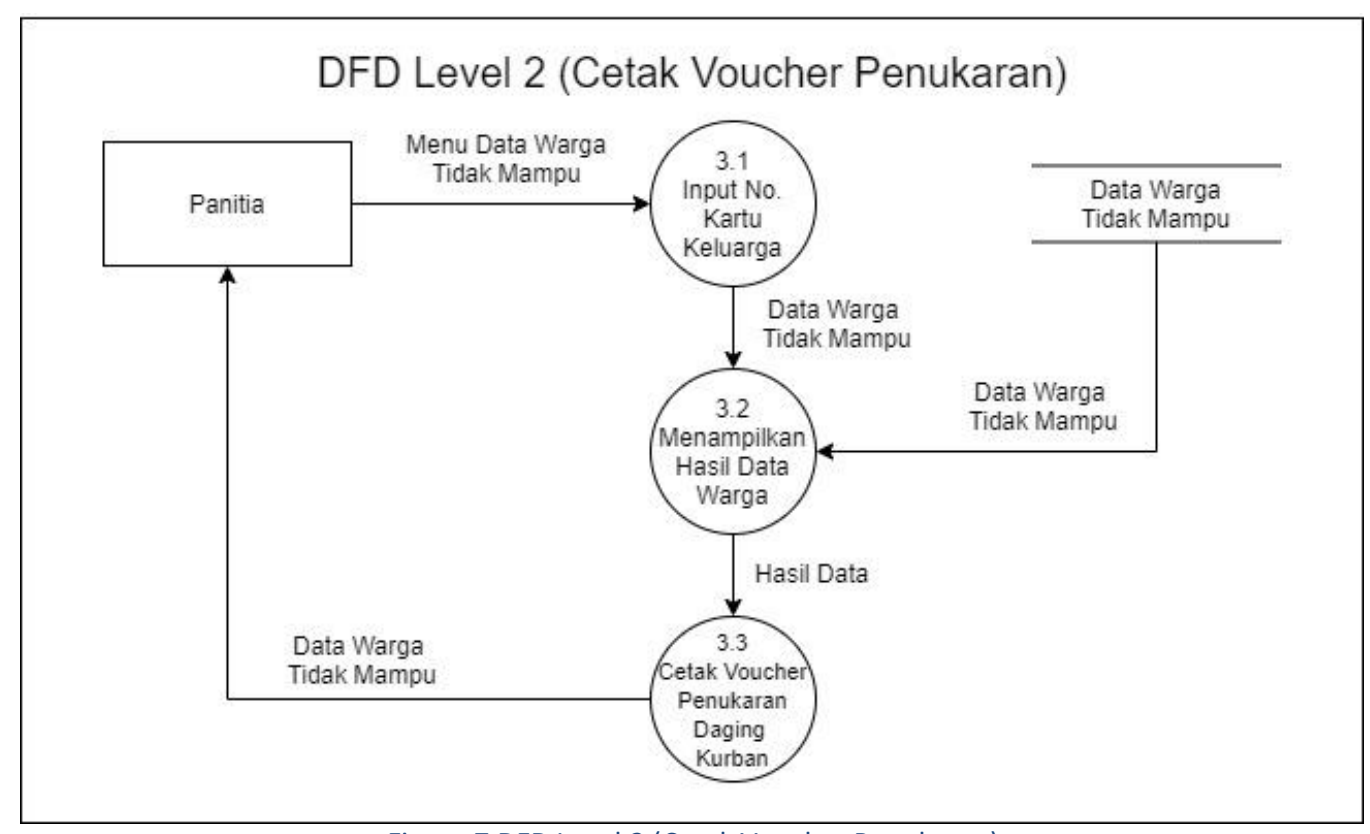

Figure 7 DFD Level 2 (Cetak Voucher Penukaran)

Pada DFD Level 2 (cetak voucher penukaran), panitia melakan input nomor kartu keluarga kemudian sistem akan menampilkan apakah nomer tersebut terdapat pada data warga tidak mampu, jika tertera maka voucher akan dicetak dan diberikan untuk warga, jika tidak maka voucher tidak dapat dicetak.

\subsection{Entity Relationship Diagram (ERD)}

Entity Relationship Diagram (ERD) dikembangkan berdasarkan teori himpunan dalam bidang matematika. Entity Relationship Diagram (ERD) digunakan untuk pemodelan basis data relational. Sehingga jika penyimpanan basis data menggunakan OODBMS maka perancangan basis data tidak perlu menggunakan ERD. [2]

Berikut merupakan ERD dari sistem informasi ini :

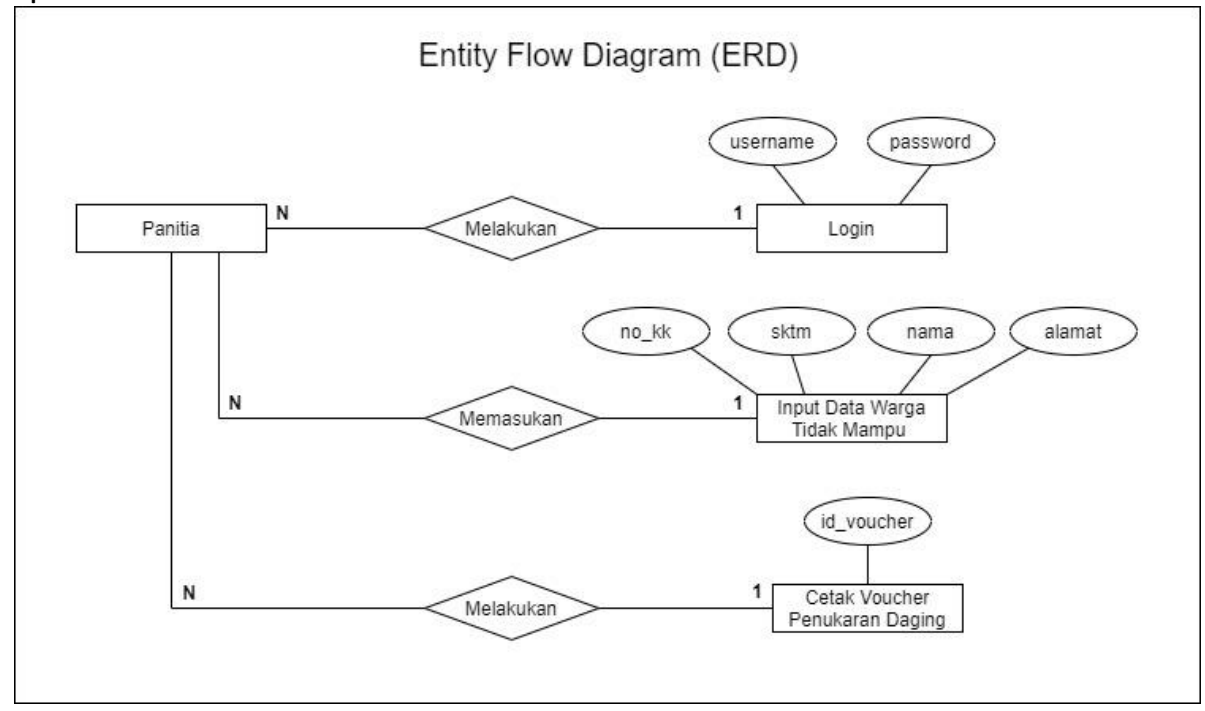

Figure 8 Entitiy Relationship Diagram (ERD)

Pada ERD ini menjelaskan apa saja yang dibutuhkan oleh setiap entitas untuk menggunakan sistem informasi ini dan apa hubungan setiap entitas. Pada login dibutuhkan username dan password. Pada input data warga tidak mampu dibutuhkan no kk, sktm, nama dan alamat, pada cetak voucher penukaran dibutuhkan id voucher. Jika tidak ada atribut tersebut maka sistem informasi ini tidak dapat digunakan. 
3.4. Database Design

Berikut merupakan database design dari sistem informasi ini :

\begin{tabular}{|c|c|c|c|c|c|}
\hline & no_kk & nama_wargi - & sktm & V & Click to Add . \\
\hline & 320103 & Firman & $\square$ & & \\
\hline & 320104 & Heru & $\nabla$ & & \\
\hline & 320105 & Dodi & $\nabla$ & & \\
\hline 米 & 0 & & $\square$ & & \\
\hline
\end{tabular}

Figure 9 Database Design

\subsection{Use Case Diagram}

Berikut merupakan use case diagram dari sistem informasi ini :

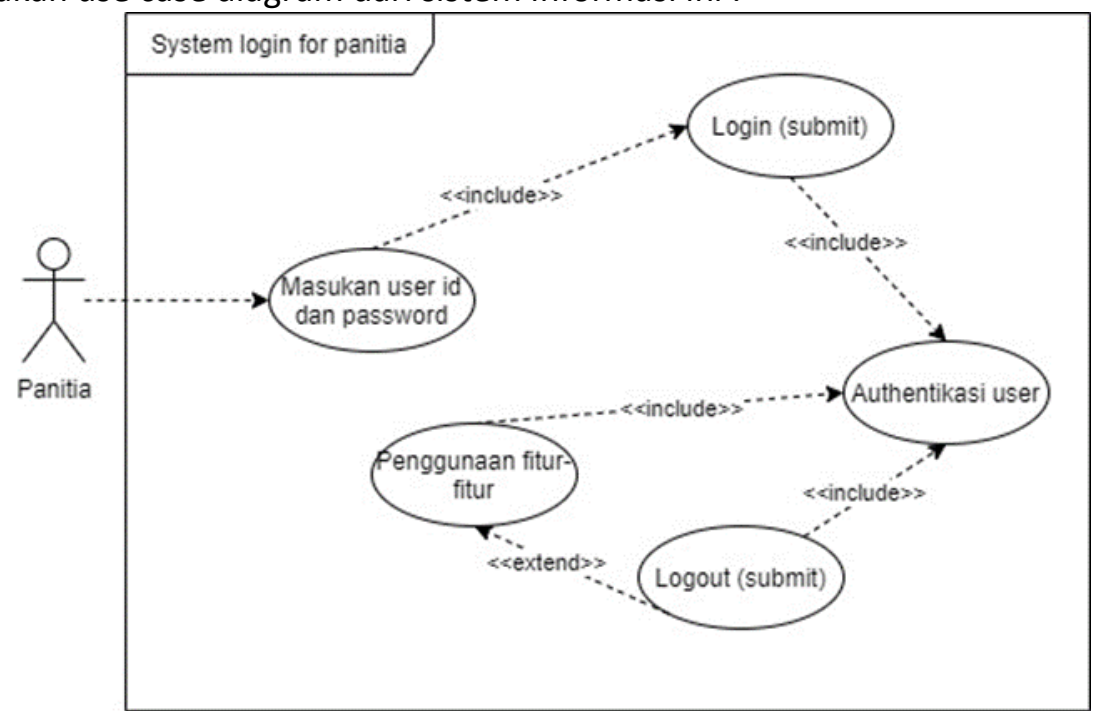

Figure 10 Use Case Diagram (Login)

Dari use case diagram ini kita dapat mengetahui apa saja yang dapat admin (panitia) saat melakukan login. 


\subsection{Activity Diagram}

Berikut merupakan activity diagram dari sistem informasi ini :

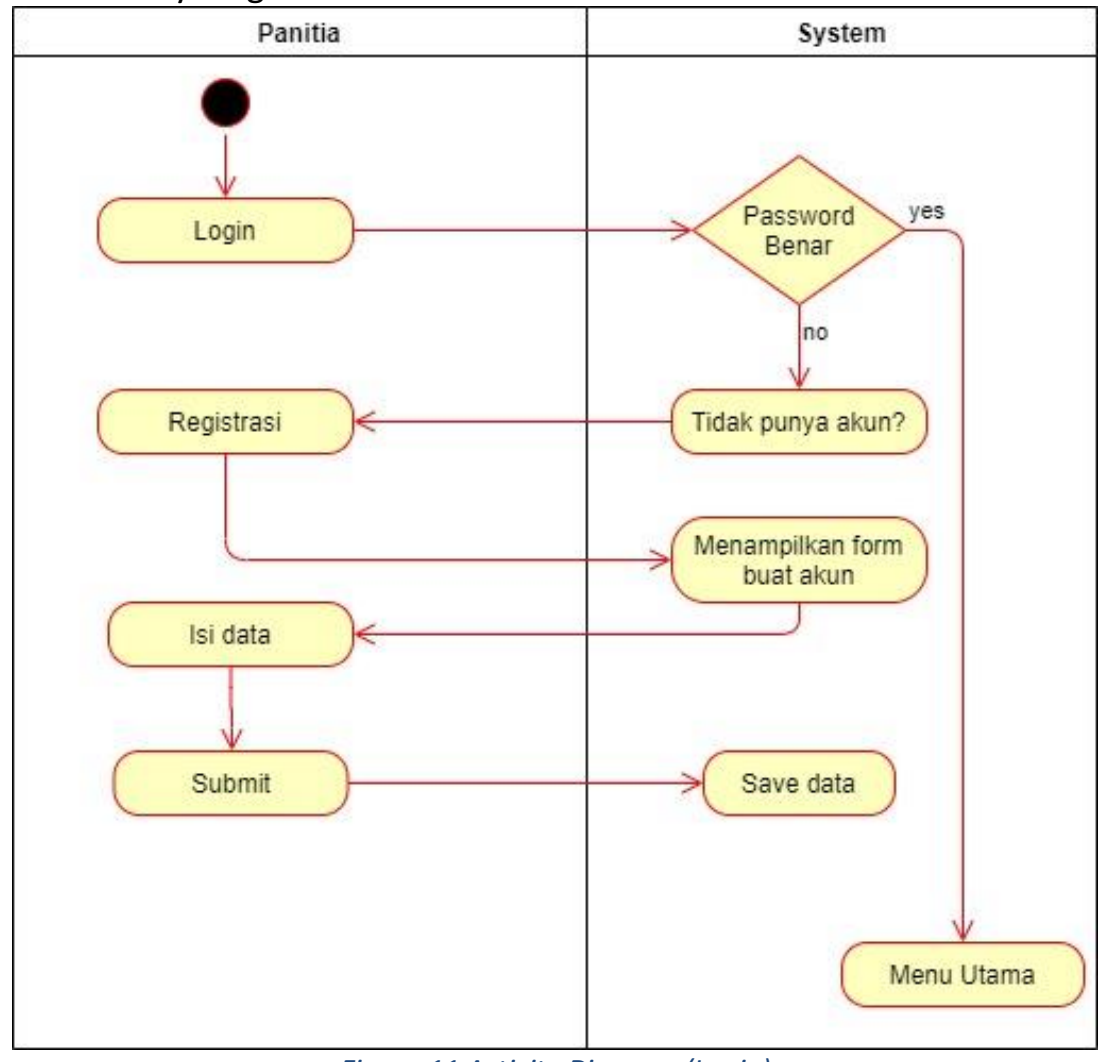

Figure 11 Activity Diagram (Login)

Proses dimulai saat panitia melakukan login kemudian sistem akan mendeteksi apakah username dan password yang dimasukan sudah sesuai atau belum. Jika sudah sistem akan meneruskan ke menu utama jika belum maka sistem akan meneruskan ke halaman register. Sistem akan menampilan form untuk membuat akun kemudian panitia akan melakukan pengisian data lalu submit dan sistem akan menyimpan data login tersebut.

\subsection{Sequence Diagram}

Berikut merupakan sequence diagram dari sistem informasi ini :

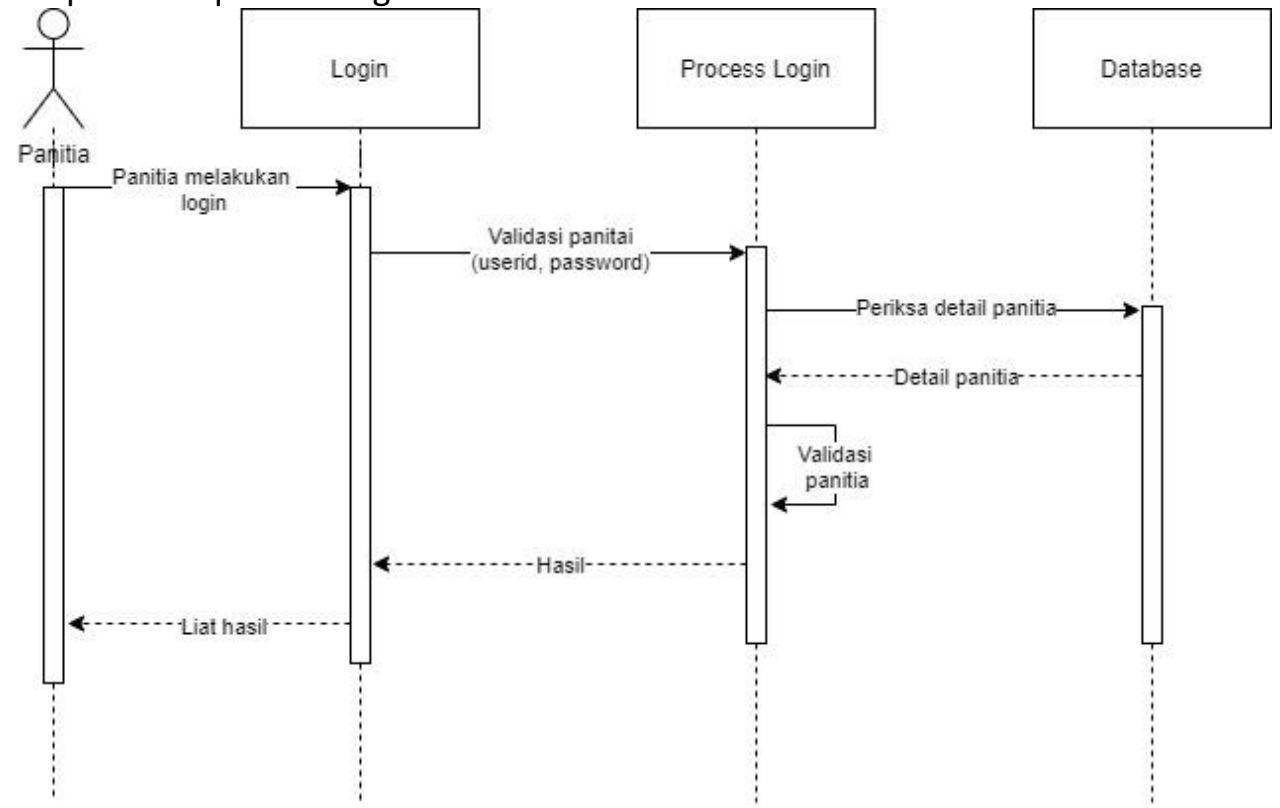

Figure 12 Sequence Diagram (Login) 
Panita melakukan login kemudian memasukan username dan password. Username dan password ini akan diperiksa di database jika benar sistem akan menampilkan hasil setelah login yaitu menu utama.

\subsection{Interface Design}

Berikut merupakan tampilan form untuk input data warga tidak mampu.

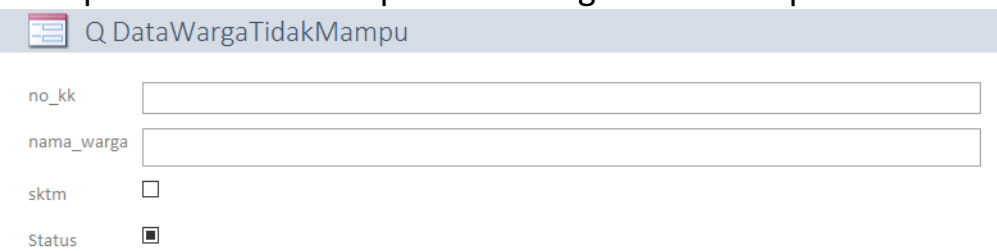

Figure 13 Tampilan Form Input Data Warga Tidak Mampu

Berikut merupakan tampilan report dari data warga tidak mampu.

$\begin{array}{cccc} & \text { Nama Warga } & \text { SkTM } & \text { Status } \\ \text { No KK } & \text { Firman } & \square & \text { Mampu } \\ 320103 & \text { Heru } & \square & \text { Tidak Mampu } \\ 320104 & \text { Dodi } & \square & \text { Tidak Mampu } \\ 320105 & & & \text { Page } 1 \text { of } 1\end{array}$

Figure 14 Tampilan Report Data Warga Tidak Mampu

\subsection{Source Code}

Berikut merupakan hasil backend source code dari sistem informasi ini :

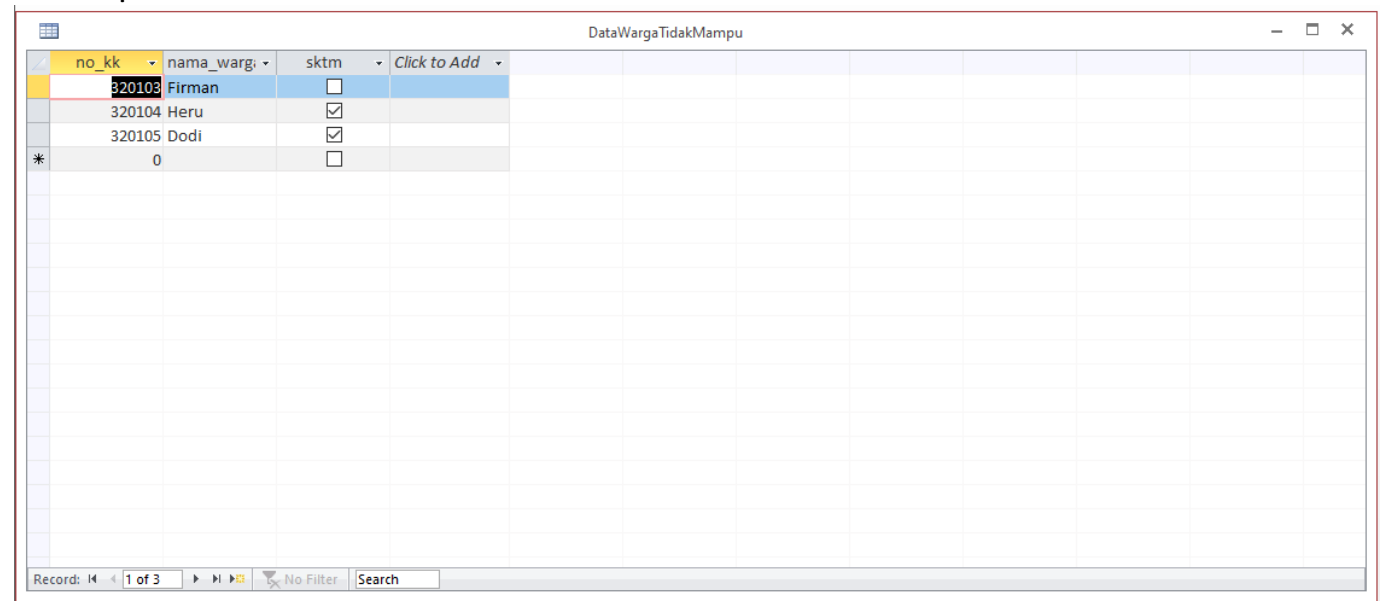

Figure 15 Backend Source Code 


\section{Penutup}

4.1 Kesimpulan

Dengan sistem informasi ini dapat membantu panitia agar memudahkan dalam pembagian daging sehingga dapat mencegah terjadinya kerusuhan. Warga yang tidak mampu akan menyerahkan surat keterangan tidak mampu (SKTM) ke panitia kurban kemudian panitia akan mendata melalui form yang sudah disediakan dan form tersebut akan terekam di database. Kemudian voucher akan diberikan kepada warga yang tidak mampu yang terdapat pada database.

\subsection{Saran}

Dalam membuat sistem informasi tersebut masih terdapat banyak kekurangan. Masih dibutuhkan saran dari pembaca seperti dengan menambahkan fitur-fitur untuk sistem informasi ini.

\section{References}

[1] R. Pressman, Rekayasa Perangkat Lunak: Pendekatan Praktisi Buku I, Yogyakarta: Andi, 2015.

[2] Sukamto\&Shalahuddin, Rekayasa Perangkat Lunak, 2014.

\section{Additional}

[a] R. Aurachman, "Review Terhadap OSF.IO Sebagai Sarana Publikasi Preprint," OSF Preprints, 17 May 2020. doi:10.31219/osf.io/rvumx , Available: https://osf.io rvumx

[b] R. Aurachman, "Kerangka Perancangan Sistem Informasi Sebagai Pembelajaran Mahasiswa Teknik Industri," osf.io, doi:10.31219/osf.io/tmpen , 5 2020. Available: https://osf.io/tmpen 